Article

\title{
Development of a Simple Method for Labeling and Identification of Protein Binders in Art
}

\author{
Su Yin Ooi ${ }^{1}$, Cátia Salvador ${ }^{1}(\mathbb{D})$, Sergio Martins ${ }^{1}$, António Pereira ${ }^{1,2}$, Ana Teresa Caldeira ${ }^{1,2, *(D)}$ \\ and João P Prates Ramalho ${ }^{2,3}$ (D) \\ 1 HERCULES Laboratory, Universidade of Évora, Largo Marquês de Marialva 8, 7000-809 Évora, Portugal; \\ ooisuyin1987@hotmail.com (S.Y.O.); Katia_salvador@hotmail.com (C.S.); \\ sergiomamartins@gmail.com (S.M.); amlp@uevora.pt (A.P.) \\ 2 Chemistry Department, School of Sciences and Technology, Universidade of Évora, Rua Romão Ramalho 59, \\ 7000-671 Évora, Portugal; jpcar@uevora.pt \\ 3 CQE, School of Sciences and Technology, Universidade of Évora, Rua Romão Ramalho 59, \\ 7000-671 Évora, Portugal \\ * Correspondence: atc@uevora.pt; Tel.: +351-266-740-800
}

Received: 30 June 2019; Accepted: 13 August 2019; Published: 16 August 2019

\begin{abstract}
Easel paintings are assets with an important historic and cultural value. They usually possess a multi-tiered structure, composed of different layers some of which may present protein binders, making it important to identify these materials for restoration and conservation purposes. We propose the identification of different protein binders by a new fluorescent labeling method employing a coumarin based chromophore, C392STP (sodium(E/Z)-4-(4-(2-(6,7-dimethoxycoumarin-3-yl)vinyl)benzoyl)-2,3,5,6-tetrafluorobenzenesulfo-nate). The method was optimized using commercial proteins and was further tested on proteins extracted from hen's egg yolk, white bovine milk, and rabbit skin glue. To model more realistic conditions, paint models of easel paintings were prepared. The paint models were made with hen's egg yolk, white bovine milk, and rabbit skin glue, mixed with different pigments and submitted to artificial aging. Then the extracted proteins from the paint models were labeled with C392 which allowed a sensitive and selective identification by polyacrylamide gel electrophoresis (PAGE) of the different protein binders used. As a final test, three 19th century easel paintings, from the Italian painter Giorgio Marini, were analyzed. The results show the potential of the proposed method for the identification of protein binders present in easel paintings.
\end{abstract}

Keywords: fluorescent labelling method; coumarins; protein binders; easel paintings; electrophoretic profiling

\section{Introduction}

Emerging in the Middle Ages, easel paintings are nowadays considered among the most important art expressions, with significant historic and cultural value. A variety of organic materials, particularly proteins from animal origin produced from egg, milk, or animal skin and bones, have been widely used in paintings as binding media, adhesives, and additives in coating layers. The wide range of organic and inorganic materials mixtures in the paintings' matrices makes the detection of the different protein materials a difficult task and contributes to the complexity of the materials identification [1-4].

Furthermore, some pigments accelerate protein degradation in the binding media [5], and chemical reactions can take place between the present organic and inorganic materials as inorganic cations that can form strong complexes with proteins [6-8]. It is, then, of paramount importance to develop analytical, low invasive approaches in protein identification not only for conservation and restauration purposes, but even for recognizing the techniques of a particular artist. 
The identification of proteins on artwork has an old history, beginning with the pioneering work of Ostwald using staining methods [9] that first allowed the identification of some protein binders. Classical colorimetric reactions, such as the Millon reaction, the Biuret reaction, or the Sakaguchi reaction, have been employed for detecting proteins in paint works [10]. A limitation of those methods, which are based on the production of visible stains, is their low sensitivity and, depending on the pigments present, difficulty differentiating the visible stains produced.

Nowadays, methods of analysis such as gas chromatography-mass spectrometry (GC-MS), liquid chromatography-mass spectrometry (LC-MS), and optical methods are at our disposal for proteinaceous binder identification in paintings and are capable to distinguish between egg, milk and animal glue proteins [11-15]. Recently, immunological techniques such as enzyme-linked immunosorbent assay (ELISA) or surfaced-enhanced Raman scattering (SERS) nanotags have been successfully used to localize/identify protein binders. A comprehensive review of the analytical developments in the detection and identification of proteins in artwork in the recent years can be found in Ref. [16].

The detection of proteins with fluorescence techniques using fluorescent organic dyes has received much attention recently. Since the use of fluorescent dyes was proposed in the late 1980s, many dyes like fluorescamine, LISSA, FITC, and DC-C7A fluorochrome have been employed $[17,18]$ for that purpose. More recently, a commercial dye containing ruthenium, the SYPRO Ruby, was used for protein detection in works of art, including paintings [19-23]. An important limitation for the use of this fluorescent dye is its high cost.

Many coumarins (benzopyranones) and coumarin derivatives have photophysical, chemical, and photochemical properties adequate for use in fluorescent labelling. Those properties include high fluorescent quantum yields and molar absorption coefficients, large Stokes shifts, and thermal and $\mathrm{pH}$ stabilities. The coumarin derivative chromophore (coumarin 392 STP ester) [24] possesses most of these properties. The chemical and photophysical properties of this coumarin derivative, its low cost, and simplicity of preparation makes it particularly suitable for labeling. Another advantage of this coumarin family of compounds is that their photophysical and spectroscopic properties can be easily designed to suit the intended application [24-26].

Furthermore, coumarin 392STP, being a 4-sulfotetrafluorophenyl coumarin ester, can efficiently label proteins by reacting with some protein amino acids [27], especially with the lysine side chain amine (Figure 1).

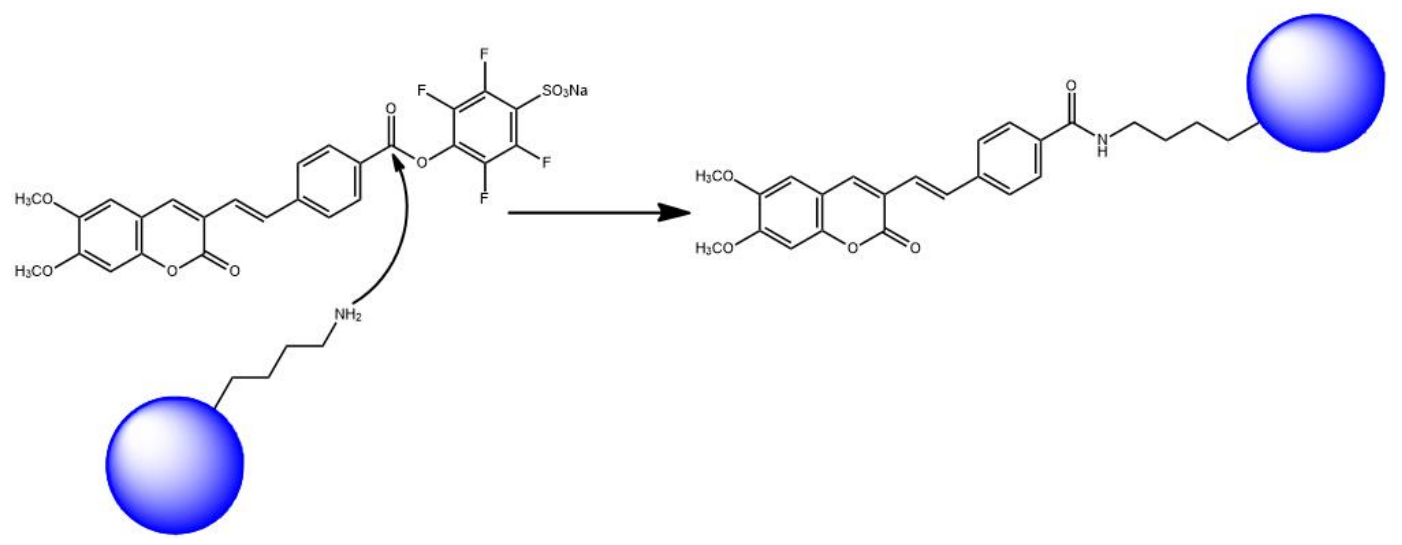

Figure 1. Reaction between Coumarin 392 STP ester and a protein side chain amino acid amine group.

This work proposes using the coumarin derivative chromophore (Coumarin 392, 4-sulfotetrafluorophenyl coumarin ester) to develop a new inexpensive and simple procedure for proteins detection and identification, particularly those employed in easel paintings. The proteinaceous extract from the paints is made react with the coumarin chromophore that binds to the proteins and its fluorescent properties allow an easy detection and identification of the proteins separated 
by gel electrophoresis. Furthermore, the step of electrophoresis gel staining is not needed in the identification process.

Taking material from works of art is a delicate matter and should be restricted to cases when it is essential to conduct a scientific cultural heritage research work, always obeying to the highest standards of professional ethics and best practices [28]. The sampling on a micro destructive method should be restricted to the minimum amount required for testing near lacunae, edges, or fissures, from the margins and reverse sides, thus avoiding aesthetic and structural damage to the work of art. To avoid unnecessary sampling, the use of a noninvasive technique can be used beforehand. Fourier transform infrared spectroscopy (FTIR) can give a hint on the presence of proteins notably by the presence of the characteristic absorption at $1653 \mathrm{~cm}^{-1}$ for the amide I and at $1550 \mathrm{~cm}^{-1}$ for the amide II. Unfortunately, this technique is not able to discriminate between different protein sources. However, only after this previous, noninvasive positive result, our technique (or another technique, like a proteomics or mass spectrometry-based technique) should be employed.

The objective of the present work is to introduce a simple, inexpensive, and effective method to complement the currently established techniques used for protein analysis, thus providing a method adequate for implementation in museum laboratories that can be used for identifying different proteins. The fluorescent labelling method was initially developed and optimized using commercial proteins and extracted proteins from natural products. After that, it was tested on proteins extracted from paint models made by mixing proteins with different pigments and submitting to artificial aging, thus mimicking easel paintings. It is known that some pigments accelerate protein degradation [5], and chemical reactions can take place between organic and inorganic materials [6-8] After confirmation of the applicability of fluorescent labelling with protein recovered from artificial, laboratory-made complex matrices, we tried it on microsamples taken from real easel paintings. The fluorescent labelling method was then tested on microsamples obtained from easel paintings of the Italian painter, Giorgio Marini (Florence, 1836-Castelo Branco, 1905). The microsamples were taken, according to conservation ethics principles, from clearly degraded areas, where visual examination found signs of alteration in the paint colors or in the structure of the painted layer.

\section{Materials and Methods}

\subsection{Fluorescent Labelling}

In this section, the method was tested with commercial proteins such as BSA (A2153), ovalbumin (A5378), and casein (C3400) (all from Sigma-Aldrich). In the first step, the commercial proteins were allowed to react with the coumarin derivative 4-sulfotetrafluorophenyl coumarin ester. The reactions were prepared by mixing the Coumarin 392 STP ester (1) $(0.00234 \mathrm{~g}, 1.0 \mathrm{mmol}, 20.0$ equiv) and the commercial proteins, in different protein: chromophore ratios and at two different temperatures, in sodium bicarbonate buffer $(4.0 \mathrm{~mL})$ and stirred for a period of $24 \mathrm{~h}$ (Table 1$)$. In test 1 , all the commercial proteins were put for labeling with protein chromophore at a ratio of $1: 20$ at room temperature $\left(25^{\circ} \mathrm{C}\right)$. After that, test 2, test 3 and test 4 were performed for commercial ovalbumin and commercial casein, with protein chromophore at ratios of $1: 20,5: 20$, and $10: 20$, respectively, at $40^{\circ} \mathrm{C}$.

Table 1. Optimization process of fluorescent labelling methodology.

\begin{tabular}{|c|c|c|c|c|}
\hline \multirow{3}{*}{\begin{tabular}{|l} 
Test Conditions \\
Proportion of Protein: Chromophore
\end{tabular}} & \multirow{3}{*}{$\begin{array}{c}\text { Test } \mathbf{1} \\
\text { BSA/Ovalbumin/Casein } \\
1: 20\end{array}$} & \multicolumn{3}{|c|}{ Test 2} \\
\hline & & \multicolumn{3}{|c|}{ Ovalbumin/Casein } \\
\hline & & $1: 20$ & $5: 20$ & $10: 20$ \\
\hline Temperature $\left({ }^{\circ} \mathrm{C}\right)$ & R.T. & \multicolumn{3}{|c|}{40} \\
\hline
\end{tabular}


2.2. Test of the Optimized Method by Using the Proteins Extracted from Hen's Egg, Bovine Milk, and Rabbit Skin Glue

\subsubsection{Protein Extraction}

Extraction of ovalbumin was based on isoelectric precipitation using trichloroacetic acid (TCA). This method uses a quantity of egg white/yolk $(10 \mathrm{~mL})$, separately, on three centrifugation steps of $10 \mathrm{~min}$ at $3000 \mathrm{rpm}$. First, $10 \mathrm{~mL} \mathrm{H}_{2} \mathrm{O}$ was used to help the dissolution and clean some of the impurities. Then, $10 \mathrm{~mL}$ of TCA 5\% was added to promote the proteins precipitation and followed by another washing step. The extracted proteins were resuspended in $10 \mathrm{~mL}$ of $\mathrm{H}_{2} \mathrm{O}$ [29].

Extraction of casein was made by precipitation with hydrochloric acid by mixing $10 \mathrm{~mL}$ of bovine milk with $10 \mathrm{~mL}$ of $\mathrm{H}_{2} \mathrm{O}$ and adding $2 \mathrm{~mL}$ hydrochloric acid $2 \%(\mathrm{HCl})$. It was then centrifuged at $2000 \mathrm{rpm}$ for $5 \mathrm{~min}$ (obtaining $2 \mathrm{~mL}$ of protein crude). The supernatant was discarded, and the precipitate was washed with $\mathrm{H}_{2} \mathrm{O}$ and centrifuged at $2000 \mathrm{rpm}$ for $10 \mathrm{~min}$. The supernatant was discarded and the final crude was resuspended in $4 \mathrm{~mL}$ of distilled water [29].

Rabbit glue was prepared in the lab using commercial rabbit glue (Sennelier) by hydration with distilled water with a ratio of $1: 9$ and then placing over a bain-marie $\left(55^{\circ} \mathrm{C}\right)$ for $30 \mathrm{~min}$. Subsequently, the samples were incubated overnight at $25{ }^{\circ} \mathrm{C}$ and then mixed with a glass stirring rod to ensure homogeneity. The glue solution was stored at $5{ }^{\circ} \mathrm{C}$

\subsubsection{Bonding of the Extracted Proteins with the Coumarin Chromophore}

After the previously described procedure in Section 2.1 has been applied to extracted proteins, a mixture of C392STP ( $0.00234 \mathrm{~g}, 1.0 \mathrm{mmol}, 20.0$ equiv) and the proteins extract, in sodium bicarbonate buffer $(4.0 \mathrm{~mL})$, was stirred for a period of $24 \mathrm{~h}$.

\subsection{Mimitize Real Conditions Using Paint Models of Easel Paintings}

\subsubsection{Constitution of Paint Models}

Paint models of easel paintings were prepared by mixing proteins extracted from hen's egg (yolk and white), bovine milk, and rabbit skin glue used as binders, and different pigments. Pigments commonly used in easel paintings such as lead white, yellow ochre and black bone were chosen (Table 2).

Table 2. Constitution of paint models.

\begin{tabular}{|c|c|c|}
\hline Paint Model & Proteic Binders & Pigments \\
\hline PM1 & \multirow{3}{*}{ Whole egg } & Lead white: $2\left(\mathrm{PbCO}_{3}\right) . \mathrm{Pb}(\mathrm{OH})_{2}(10 \mathrm{~g})$ \\
\hline PM2 & & Yellow ochre: $\mathrm{FeO}(\mathrm{OH})$ \\
\hline PM3 & & Black bone: $\mathrm{Ca}_{5}(\mathrm{OH})\left(\mathrm{PO}_{4}\right)_{3}$ and $\mathrm{C}$ \\
\hline PM4 & \multirow{3}{*}{ Bovine milk } & Lead white: $2\left(\mathrm{PbCO}_{3}\right) . \mathrm{Pb}(\mathrm{OH})_{2}(10 \mathrm{~g})$ \\
\hline PM5 & & Yellow ochre: $\mathrm{FeO}(\mathrm{OH})$ \\
\hline PM6 & & Black bone: $\mathrm{Ca}_{5}(\mathrm{OH})\left(\mathrm{PO}_{4}\right)_{3}$ and $\mathrm{C}$ \\
\hline PM7 & \multirow{3}{*}{ Rabbit skin glue } & Lead white: $2\left(\mathrm{PbCO}_{3}\right) \cdot \mathrm{Pb}(\mathrm{OH})_{2}(10 \mathrm{~g})$ \\
\hline PM8 & & Yellow ochre: $\mathrm{FeO}(\mathrm{OH})$ \\
\hline PM9 & & Black bone: $\mathrm{Ca}_{5}(\mathrm{OH})\left(\mathrm{PO}_{4}\right)_{3}$ and $\mathrm{C}$ \\
\hline
\end{tabular}

The ratio of binder to pigment was 1:3. Mixtures layers with thickness between 50-150 $\mu \mathrm{m}$ (Figure 2) were applied on glass supports. The easel painting paint models were then placed in the aging chamber for one month to undergo the aging process artificially. The aging process was carried 
out in three cycles. Each cycle consisted of five days in a relative humidity of $85 \%$ and a temperature of $45^{\circ} \mathrm{C}$, followed by five days in a relative humidity of $30 \%$ and a temperature of $12{ }^{\circ} \mathrm{C}$.

(a)

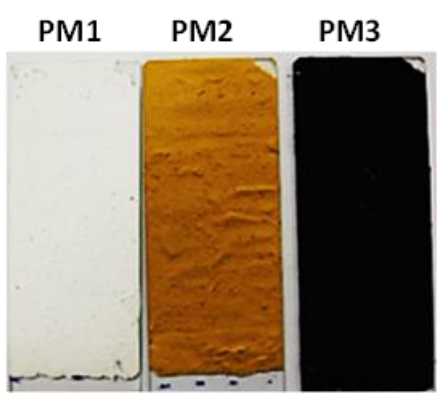

(b)

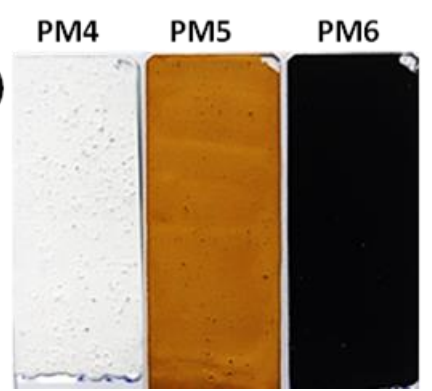

(c)

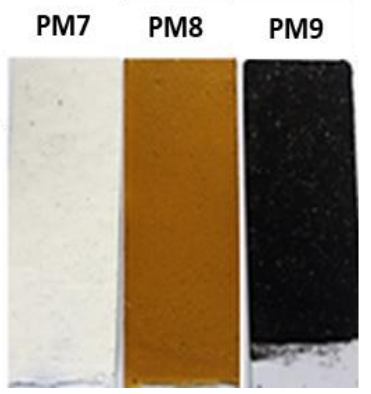

Figure 2. Easel painting models prepared using hen's egg as binder (a), bovine milk (b), and rabbit skin glue (c) with three different pigments: Lead white, yellow ochre, and black bone.

2.3.2. Protein Extraction from Paint Models Microsamples and Bonding with the Coumarin Chromophore

The samples were obtained from the paint models microsamples (PM1-PM9). Then, each sample was suspended in $1 \mathrm{~mL}$ of sodium bicarbonate buffer. The proteins were extracted in three cycles consisting of a sonification step during $1 \mathrm{~h}$ and an incubation step at $37^{\circ} \mathrm{C}$ with orbital agitation during $1 \mathrm{~h}$, followed by an overnight incubation at $37^{\circ} \mathrm{C}$ as described by Salvador et al., 2017 [30].

The proteinaceous content, which was extracted from the paint microsamples, was determined using the Bradford method [31]. The total protein content of the microsamples was expressed as $\mu \mathrm{g}$ of BSA equivalents per milligram of microsample. The concentrations of proteins extracted from paint models range from $7.28-27.57 \mu \mathrm{g} / \mathrm{mL}$. After determining the protein content extracted, they were bonded with C392STP using the method described in Section 2.1, with the reduced amount of chromophore $(0.025 \mathrm{mg} / \mathrm{mL})$ and the total volume of reaction $(1 \mathrm{~mL})$ to avoid excess chromophore.

\subsection{Spectroscopy Analyses}

The experimental UV-visible absorption spectra of C392STP, unbonded commercial proteins and extracted proteins, and fluorescent commercial proteins and fluorescent extracted proteins were recorded using a Thermo Electron Corporation (Nicolet Evolution 300) spectrophotometer.

\subsection{Electrophoretic Separation by PAGE}

The electrophoretic profiles of proteins and the proteins bonded to coumarin derivative chromophore were analyzed by polyacrylamide gel electrophoresis (PAGE). After the polymerization of gel (Acrylamide: Bisacrylamide (30:0.8)) was completed, electrophoresis was prepared using the MiniPROTEAN equipment from Bio-Rad. The gel was placed on the support and the electrophoresis buffer (Tris $25 \mathrm{mM}$ with glycine $0.192 \mathrm{M}, \mathrm{pH}$ 8.3) was added. Samples were prepared by mixing $15 \mu \mathrm{L}$ of sample with $10 \mu \mathrm{L}$ of loading buffer $(20 \mu \mathrm{g} / \mathrm{mL}$ of bromophenol blue and $10 \%$ of glycerol at $87 \%$ in Tris- $\mathrm{HCl}$ buffer $62.5 \mathrm{mM}, \mathrm{pH} 6.8)$ and were applied in the wells ( $25 \mu \mathrm{L}$ per well). In addition, NZY Colour Protein Marker II (Nzytech) with molecular weight (MW) between 11 and $245 \mathrm{kDa}$ was used as the molecular marker and was applied in the wells of the acrylamide gel ends. Electrophoretic run was started at a potential difference of $100 \mathrm{~V}$ until the bromophenol blue travel throughout the gel. The gels were visualized in a UV chamber (Molecular Imager, Gel Doc XR+ Imaging System, Bio-Rad), analyzed and results recorded using the Image Lab 5.0 software (Copyright 2013, Bio-Rad Laboratories).

\subsection{Easel Paintings Microsamples: Protein Extraction and Bonding with Coumarin Chromophore}

The method was applied to three easel paintings by Giorgio Marini (1836-1905): The portrait of Frei Manuel do Cenáculo (ME1281, dated 1887) from the Museum of Évora, the portrait of a 
bearded gentleman (dated 1897), and the portrait of a lady (dated 1886), from private collections. All these paintings present evident chromatic and structural alterations and the sampling process was made according to the conservation ethics, collecting the minimum amount required for the tests. Microsamples were collected by scrapping off $800-1000 \mu \mathrm{g}$ from the painting layers using a microscalpel.

The protein content was extracted from easel paintings microsamples using an optimized methodology as described in the Section 2.3.2 [30]. After these procedures, the protein extracts obtained were then submitted to the fluorescent labelling method.

The protein extracted was bonded with C392STP using the developed fluorescent labelling method. The reactions were prepared by mixing the C392STP, at the concentration of $0.025 \mathrm{mg} / \mathrm{mL}$, and the proteins recovered from easel paintings, in sodium bicarbonate buffer with a total volume of $(1.0 \mathrm{~mL})$ and stirring for a period of $24 \mathrm{~h}$. Table 3 shows the conditions of the fluorescent labelling reactions performed. Identification of the fluorescent proteins produced was done by electrophoretic separation by PAGE.

Table 3. Conditions for the fluorescent labelling of easel paintings microsamples.

\begin{tabular}{cc}
\hline Reactions & Volume \\
\hline M2 & $100 \mu \mathrm{L}$ of protein extract from microsamples \\
Portrait of Frei Manuel do Cenáculo, 1887, (ME1281) & $0.25 \mathrm{~mL}$ of $0.25 \mathrm{mg} / \mathrm{mL}$ C392STP \\
& $0.75 \mathrm{~mL}$ of phosphate buffer \\
\hline Mb & $100 \mu \mathrm{L}$ of protein extract from microsamples \\
Portrait of a bearded gentleman, 1897 & $0.25 \mathrm{~mL}$ of $0.25 \mathrm{mg} / \mathrm{mL} \mathrm{C392STP}$ \\
& $0.75 \mathrm{~mL}$ of phosphate buffer \\
\hline Md & $100 \mu \mathrm{L}$ of protein extract from microsamples \\
Portrait of a lady, 1886 & $0.25 \mathrm{~mL}$ of $0.25 \mathrm{mg} / \mathrm{mL}$ C392STP \\
& $0.75 \mathrm{~mL}$ of phosphate buffer \\
\hline
\end{tabular}

\section{Results and Discussion}

\subsection{Spectroscopic Characteristics}

UV spectroscopic characteristics of free coumarin 392 STP ester were determined before exploring the bonding with commercial proteins. The UV spectrum of coumarin 392 STP ester is shown in Figure 3 while Figure 4 shows the UV spectra of the unbonded proteins and fluorescent proteins. From the UV spectrum of coumarin 392 STP ester, a peak was found at the wavelength of $381 \mathrm{~nm}$.

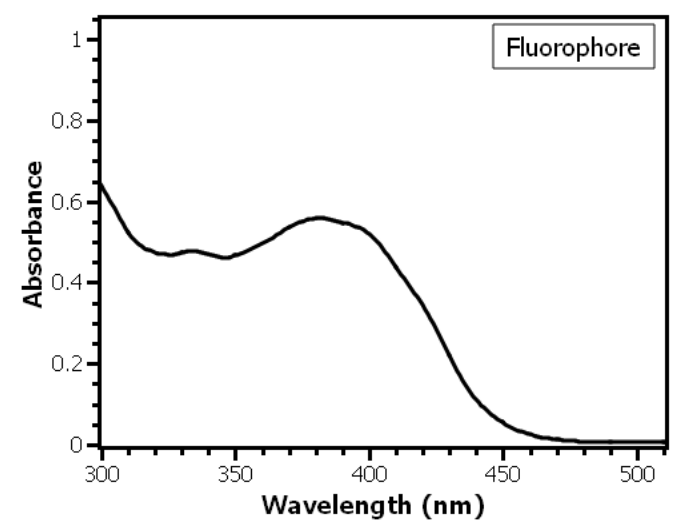

Figure 3. UV spectra of coumarin 392 STP ester. 

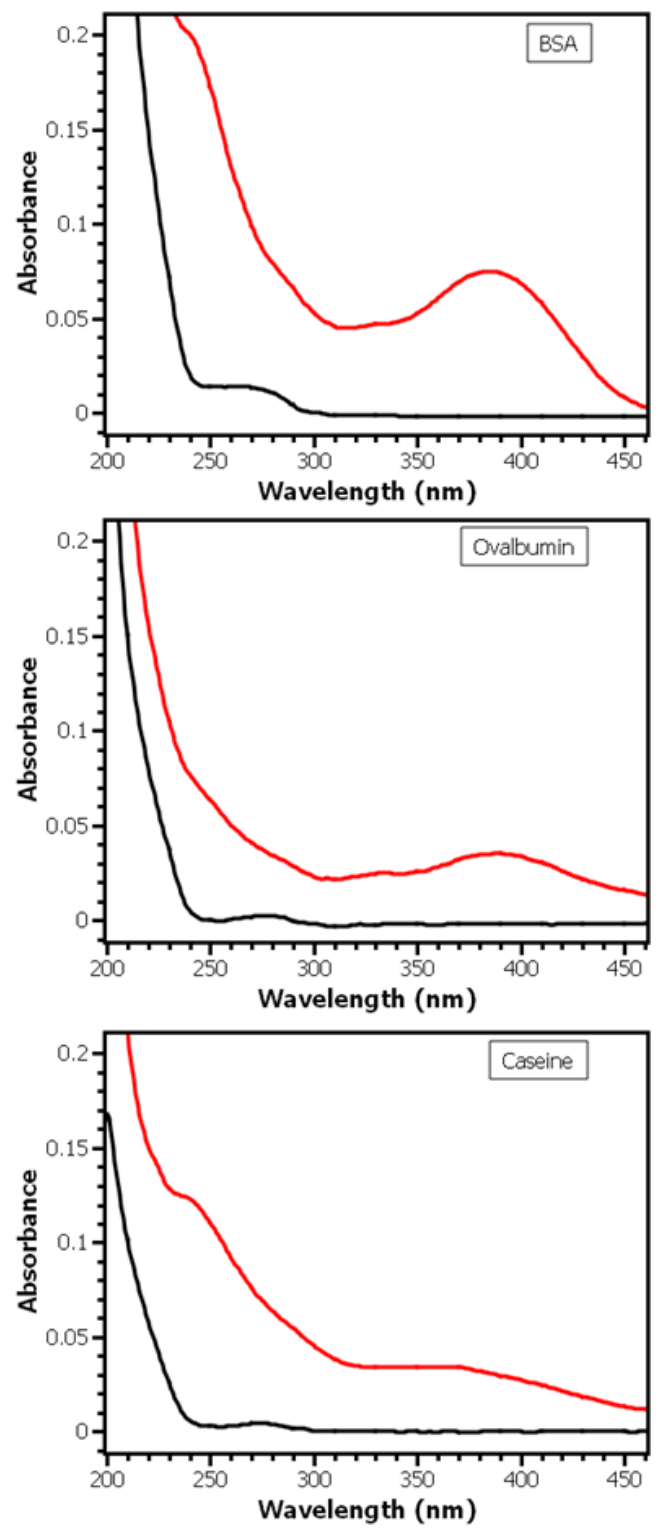

Figure 4. UV spectra of the unbonded (black) and fluorescent labelled (red) proteins.

As described above, in the first stage of fluorescent labelling methodology, commercial proteins were tested to bond with Coumarin 392 STP ester. Through the UV spectra obtained, a peak was observed in all commercial proteins tested which is not present on the unbonded commercial proteins. The maxima were found at the wavelengths of 384,389 , and $374 \mathrm{~nm}$ for BSA, ovalbumin, and casein, respectively. Those maxima between $374-389 \mathrm{~nm}$, observed in the fluorescent protein spectra, are near to the peak that was found in the free Coumarin 329 STP ester, which suggests that the fluorescence characteristics of free Coumarin 329 STP ester were found in all the labelled proteins. Fluorescent proteins produced are excited around $374-389 \mathrm{~nm}$, which is near the emission peaks of mercury lamps $(365 \mathrm{~nm})$ [32]. This characteristic allows fluorescent effect to be observed.

\subsection{Electrophoretic Profiles of Commercial and Extracted Proteins}

To proceed with the identification of the different proteins, electrophoresis in polyacrylamide gel was used. Electrophoretic profiles of unbonded proteins and the proteins labeled with the coumarin derivative chromophore were analyzed for the determination of the characteristic profiles (Table 4). 
Table 4. Molecular weight $(\mathrm{kDa})$ of the commercial proteins (a) and extracted proteins $(\mathbf{b})$ displayed in polyacrylamide gel electrophoresis (PAGE) profiles.

\begin{tabular}{|c|c|c|c|c|c|c|c|c|}
\hline \multirow{6}{*}{$\begin{array}{l}\text { Commercial } \\
\text { Proteins (a) }\end{array}$} & \multicolumn{2}{|c|}{ BSA } & \multicolumn{2}{|c|}{ Ovalbumin } & \multicolumn{2}{|c|}{ Casein } & \multicolumn{2}{|c|}{ Collagen } \\
\hline & Unbonded & Fluorescent & Unbonded & Fluorescent & Unbonded & Fluorescent & Unbonded & Fluorescent \\
\hline & 200.8 & $100-135$ & 64.1 & $63-75$ & 66.6 & $63-75$ & $35-48$ & $35-48$ \\
\hline & 160.5 & $63-100$ & 46.3 & $48-63$ & 38.0 & $48-63$ & & \\
\hline & 101.4 & 63-75 & 40.0 & $25-35$ & & $35-48$ & & \\
\hline & 52.4 & $35-48$ & 36.0 & $20-25$ & & & & \\
\hline \multirow{7}{*}{$\begin{array}{c}\text { Extracted } \\
\text { Proteins (b) }\end{array}$} & \multicolumn{4}{|c|}{ Ovalbumin } & \multicolumn{2}{|c|}{ Casein } & \multicolumn{2}{|c|}{ Collagen } \\
\hline & \multicolumn{2}{|c|}{ Unbonded } & \multicolumn{2}{|c|}{ Fluorescent } & Unbonded & Fluorescent & Unbonded & Fluorescent \\
\hline & (Egg Yolk) & (Egg White) & (Egg Yolk) & (Egg White) & \multicolumn{2}{|c|}{ Casein (milk) } & \multicolumn{2}{|c|}{ Rabbit glue } \\
\hline & 195.8 & 177.9 & $>180$ & 135-180 & 69.6 & $63-75$ & $63-75$ & $63-75$ \\
\hline & 111.7 & 109.6 & 100-135 & 100-135 & 39.9 & $35-48$ & & \\
\hline & 64.0 & & $63-75$ & & & & & \\
\hline & & & $48-63$ & & & & & \\
\hline
\end{tabular}

The PAGE separated the proteins according to their charge and its molecular weight, based on its structure. Through the electrophoresis performed for commercial proteins without the linkage to the coumarin derivative chromophore, BSA had the higher number of heavy chains. Four distinct proteic bands were observed for BSA $(200.8,160.5,101.4$, and $52.4 \mathrm{kDa})$ and three heavy chains between 200.8-101.4 kDa. The result found was similar to the result reported in the previous work, which showed protein bands of BSA with MW of 198, 132, and $66 \mathrm{kDa}$ [29]. Four distinct protein bands were observed for ovalbumin $(64.1,46.3,40.0$, and $36.0 \mathrm{kDa})$ and casein presented two bands at 66.6 and $38.0 \mathrm{kDa}$, while collagen presented one band ranged between $35-48 \mathrm{kDa}$. Furthermore, it was found that the lowest concentration that produces clear bands, for both unlabeled commercial ovalbumin and casein, was $0.0625 \mathrm{mg} / \mathrm{mL}$.

On the other hand, electrophoresis was also performed with the commercial proteins bonded with C392 after each step of the optimization process (Table 1). In test 1, commercial BSA has bonded successfully with C392. Four distinct protein bands, between 35 and $135 \mathrm{kDa}$, appeared in the electrophoresis gel (Table 3). However, the electrophoretic profiles of ovalbumin and casein were not clearly shown. Thus, the optimization process proceeded to test 2 , test 3 , and test 4 by increasing the temperature to $40^{\circ} \mathrm{C}$ with three different ratios of $\mathrm{C} 392$ to protein. In this case, four distinct protein bands, between 20 to $75 \mathrm{kDa}$, were observed for commercial ovalbumin, while three protein bands, between 35 to $75 \mathrm{kDa}$, were observed for commercial casein, showing that ovalbumin and casein bonds more effectively with C392 in slightly increased temperature $\left(40^{\circ} \mathrm{C}\right)$ conditions. Test 2 was then chosen for the detection of ovalbumin and casein in order to minimize the amount of protein needed.

In the next step, the optimized procedure has been applied on the protein extracted from hen's egg and milk. Ovalbumin extracted from egg yolk consists of three clear bands at 195.8, 111.7, and $64.0 \mathrm{kDa}$, while one weak band was around $48 \mathrm{kDa}$. On the other hand, two distinct bands were seen for ovalbumin extracted from egg white (177.9 and $109.6 \mathrm{kDa}$ ) and casein extracted from milk (69.6 and $39.9 \mathrm{kDa}$ ). Furthermore, in the electrophoresis gel of fluorescent extracted proteins, three clear proteic bands were seen for ovalbumin from egg yolk and casein, while four protein bands were observed for ovalbumin from egg white.

On the other hand, for the fluorescent labelled rabbit glue, a clear band is seen between 63 and $75 \mathrm{kDa}$, evidencing once more the detection capability of this methodology. Despite that, the protein bands appeared around the same positions, which means that the molecular weight of both commercial proteins and extracted proteins were similar.

Figure 5 shows the electrophoresis gel for the extracted proteins from the paint microsample. Interestingly, fluorescent band were observed at 25-35 kDa for extracted ovalbumin (PM1-PM3), which is in line with the band observed from fluorescent commercial ovalbumin and fluorescent ovalbumin from egg yolk. Additionally, a clear fluorescent band was found at $100-135 \mathrm{kDa}$ for the extracted casein from the paint model. The electrophoretic profile showed similar characteristic band profiles for the extracted and the commercial proteins. Fluorescent bands were observed at the same area $(25-35 \mathrm{kDa})$ 
for the paint models which contains same protein (ovalbumin) and different pigments (PM1, PM2, and PM3), while fluorescent bands were also observed at the same area (100-135 kDa) for the paint models containing casein with different pigments (PM4, PM5, PM6). On the other hand, the electrophoretic profiles of rabbit skin glue and fluorescent rabbit glue extracted from the paint microsamples (PM7, PM8, PM9) showed coincident patterns, permitting to identify collagen proteinaceous binders in the painting matrices. The fluorescent bands, characteristic of proteins, were clearly visible even after the accelerated aging process that can promote complex modifications of the proteinaceous binders.

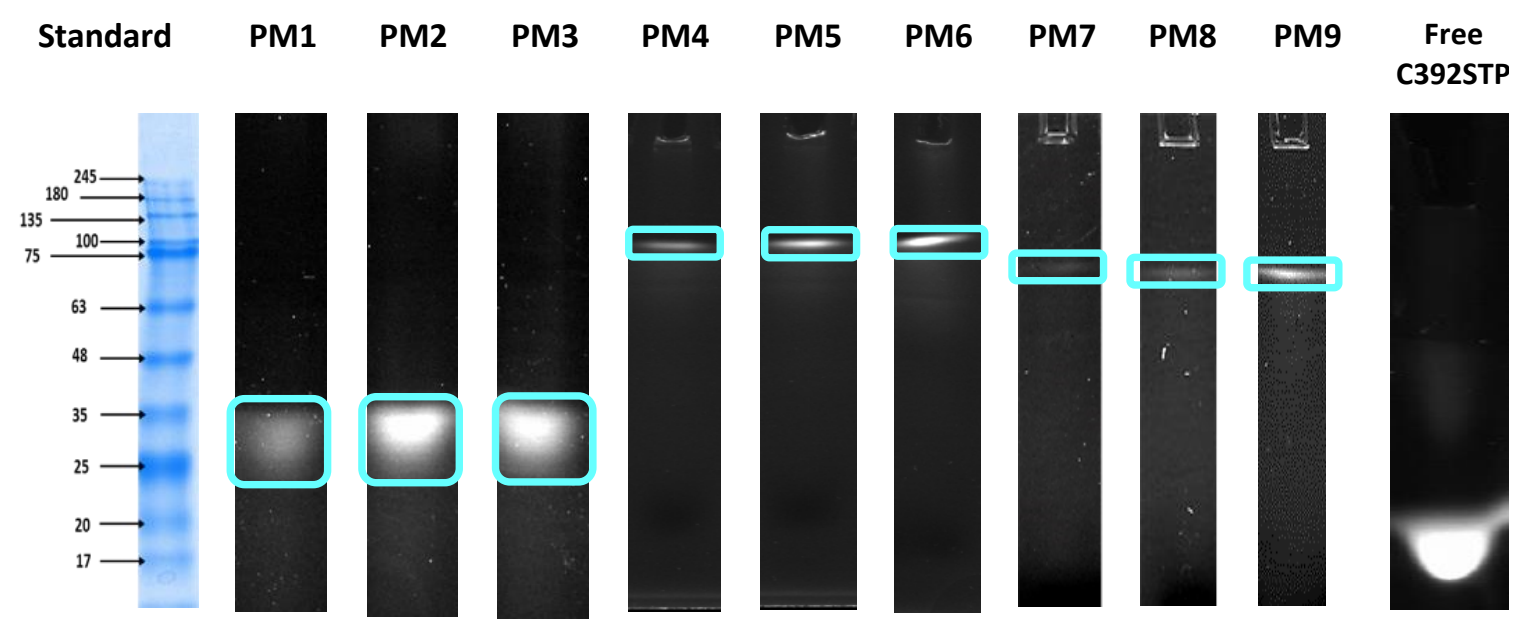

Figure 5. Electrophoretic profile of proteins extracted from paint models bounded with fluorescent coumarin 392 STP ester.

The results showed that is possible to extract and detect these protein binders from different matrices in the presence of several different pigments. The protein content at the concentrations ranged from $6.42-17.42 \mu \mathrm{g} / \mathrm{mL}$ (ovalbumin paint models), 10.10-27.95 $\mu \mathrm{g} / \mathrm{mL}$ (casein paint models), and $6.49-33.58 \mu \mathrm{g} / \mathrm{mL}$ (rabbit glue paint models) can be labelled with C392STP. The fluorescent proteins produced can be easily detected using spectroscopic methods as well as electrophoresis.

These results also indicated that the method shows high sensitivity, considering that it was able to detect protein binders from paint model microsamples with protein content as low as $6.57 \mu \mathrm{g} / \mathrm{mL}$ (proteins extracted from paint models range from $6.49-33.58 \mu \mathrm{g} / \mathrm{mL}$ ), while the lowest concentration detected from unlabeled commercial protein samples was $0.0625 \mathrm{mg} / \mathrm{mL}$. Thus, it is concluded that the origins of the proteins obtained from the aged paint models, corresponding to different matrices and pigments, can be identified with this methodology.

\subsection{Application of Fluorescent Labelling Methodology on Easel Paint Microsamples}

The extracted proteins recovered from samples of easel paintings by Giorgio Marini (1836-1905) were submitted to the fluorescent labelling method as described before. The electrophoretic profiles obtained from the different paint microsamples compared with the electrophoretic profiles obtained from paint models with different protein binders are depicted in Figure 6. 


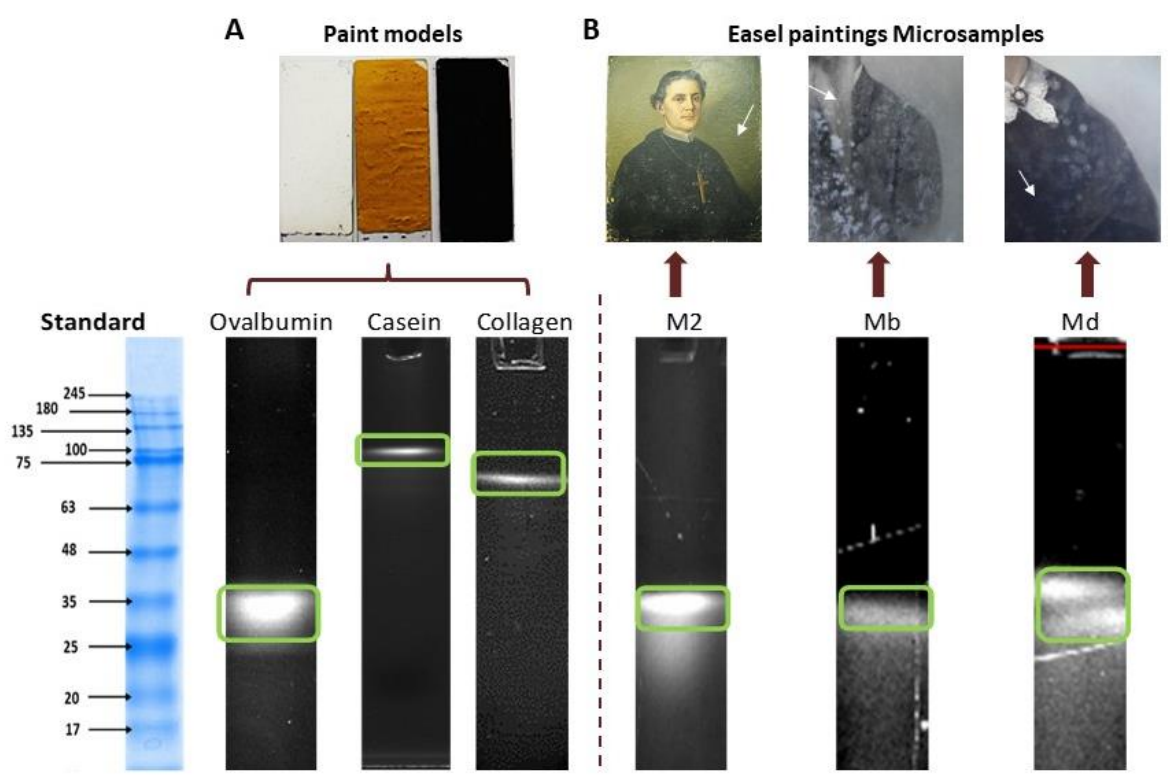

Figure 6. Electrophoresis profiles of microsamples extracted from paint models (A) and extracted from easel paintings (B) M2-Portrait of Frei Manuel do Cenáculo, 1887, (ME1281), Museum of Évora (Évora, Portugal); Mb-Portrait of a Bearded Gentleman, 1897; and Md-Portrait of a Lady, 1886, private collection (Évora, Portugal).

The results clearly show that ovalbumin is present in all three paintings, and no other proteins are observed. These paintings have been studied in an earlier study by an optimized immunoassay based on indirect ELISA with commercial antibodies [30], with ovalbumin being found in all samples analyzed. In some of the samples, it was also possible to find the presence of collagen and casein, in most cases under the limit levels for quantification.

These results show that the method is capable to detect and identify protein binders from real paintings microsamples, corresponding to low amounts of proteins present in complex solid media and subject to the effects of time and environment conditions.

Advantages of this new fluorescent labelling method is that the coumarin derivative ester used can be synthesized easily, at low cost, with a long wavelength, which is significantly important for biological purposes. Furthermore, it has good solubility in the reaction buffer media. In fact, it was shown that 4-Sulfo-2,3,5,6-tetrafluorophenyl (STP) esters have higher water solubility when compared with $N$-hydroxysuccinimidyl (NHS) esters [27]. This is an important characteristic for the application in biological research because it solves the problem of hydrophobicity of some previously used labelling fluorophores [33]. The linkage of proteins with this coumarin chromophore produces clear bands through electrophoresis in native conditions without requiring the step of electrophoresis gel staining. It makes the labelling process easy and rapid. The results also show that this method can be applied on the labelling of paint microsamples with minimal amount of C392. Clear bands can be observed for all the labelled proteins extracted from paint microsamples, although the amount of chromophore was reduced from 0.585 to $0.025 \mathrm{mg} / \mathrm{mL}$ in the labelling process.

\section{Conclusions}

In this work, a low-cost coumarin is explored as a new fluorescent protein label oriented for the detection and identification of proteins present in easel paintings. The C392STP coumarin properties, including its capability to react with protein primary amine groups, make it particularly adequate for biolabeling. Fluorescent labeled proteins thus produced can be detected by gel electrophoresis without the need of electrophoresis gel staining. 
We have optimized the labelling method using commercial proteins like BSA, ovalbumin, and casein, as well as proteins extracted from bovine milk and chicken eggs (yolk and white). The optimized protocol has been applied on laboratory paint models of easel paintings, prepared by mixing egg and bovine milk proteins with different pigments commonly used in easel paintings and submitted to an artificial process of aging. The fluorescent labelling method was tested and the results revealed that proteins in a concentration as low as $6.0 \mu \mathrm{g} / \mathrm{mL}$ could be detected.

As a realistic application, three easel paintings from the Italian painter Giorgio Marini were analyzed. The results revealed that ovalbumin is present in all three paintings, which agrees with previous ELISA studies conducted in Marini's paintings [30].

Considering the reported results, the method shows potential as an effective tool for protein binder identification in works of art, particularly in easel paintings. Although the method requires microsampling from the artworks, only small amounts of sample are required for the analysis. On the other hand, the method is inexpensive, only requiring equipment commonly found in a chemistry/biochemistry laboratory, thus making it adequate for implementation in museum laboratories. The simplicity, the good results of the methods, and the economic aspect constitute important attractive features of this approach.

Author Contributions: Methodology, O.S.Y., C.S. and S.M.; writing-original draft preparation, O.S.Y. and C.S.; conceptualization, A.P., J.P.P.R. and A.T.C.; writing-review and editing, O.S.Y., C.S., J.P.P.R. and A.T.C.; conceptualization, A.P., J.P.P.R. and A.T.C.

Acknowledgments: The authors gratefully acknowledge the funding source to project "The SCREAM-Touchstone for Heritage Endangered by Salt Crystallization - a Conservation Research" ref. FCT-ALT20-03-0145-FEDER-031577 and "MEDUSA-Microrganisms Monitoring and Mitigation-Developing and Unlocking Novel Sustainable Approaches" ref. ALT20-03-0145-FEDER-000015, co-financed by the European Union through the European Regional Development Fund ALENTEJO 2020 (Regional Operational Programme of the Alentejo). Ooi Su Yin acknowledge gLINK Project for their grant and Sergio Martins FCT under SFRH/BD/128807/2017 grant.

Conflicts of Interest: The authors declare no conflict of interest.

\section{References}

1. Vagnini, M.; Pitzurra, L.; Cartechini, L.; Miliani, C.; Brunetti, B.G.; Sgamellotti, A. Identification of proteins in painting cross-sections by immunofluorescence microscopy. Anal. Bioanal. Chem. 2008, 392, 57-64. [CrossRef] [PubMed]

2. Manzano, E.; Navas, N.; Checa-Moreno, R.; Rodriguez-Simón, L.; Capitán-Vallvey, L.F. Preliminary study of UV ageing process of proteinaceous paint binder by FT-IR and principal component analysis. Talanta 2009, 77, 1724-1731. [CrossRef] [PubMed]

3. Romero-Pastor, J.; Navas, N.; Kuckova, S.; Rodríguez-Navarro, A.; Cardell, C. Collagen based proteinaceous binder-pigment interaction study under UV ageing conditions by MALDI-TOF-MS and principal component analysis. J. Mass Spectrom. 2012, 47, 322-330. [CrossRef] [PubMed]

4. Pellegrini, D.; Duce, C.; Bonaduce, I.; Biagi, S.; Ghezzi, L.; Colombini, M.P.; Tinè, M.P.; Bramanti, E. Fourier transform infrared spectroscopic study of rabbit glue/inorganic pigments mixtures in fresh and aged reference paint reconstructions. Microchem. J. 2016, 124, 31-35. [CrossRef]

5. Ren, F.; Atlasevich, N.; Baade, B.; Loike, J.; Arslanoglu, J. Influence of pigments and protein aging on protein identification in historically representative casein-based paints using enzyme-linked immunosorbent assay. Anal. Bioanal. Chem. 2016, 408, 203-215. [CrossRef] [PubMed]

6. Duce, C.; Ghezzi, L.; Onor, M.; Bonaduce, I.; Colombini, M.P.; Tine, M.R.; Bramanti, E. Physico-chemical characterization of protein-pigment interactions in tempera paint reconstructions: Casein/cinnabar and albumin/cinnabar. Anal. Bioanal. Chem. 2012, 402, 2183-2193. [CrossRef] [PubMed]

7. Colombini, M.P.; Gautier, G. GC/MS in the Characterisation of Protein Paint Binders; John Wiley \& Sons: Chichester, UK, 2009; pp. 237-260.

8. Colombini, M.P.; Andreotti, A.; Bonaduce, I.; Modugno, F.; Ribechini, E. Analytical strategies for characterizing organic paint media using gas chromatography/mass spectrometry. Acc. Chem. Res. 2010, 43, 715-727. [CrossRef] [PubMed] 
9. Ostwald, W. Iconoscopic studies I: Microscopic identification of homogenous binding mediums. Technol. Stud. Field F. A. 1936, 4, 135-144.

10. Gay, M.C. Essais d'identification et de localisation des liants picturaux par des coloration specifiques sur coupes minces. Ann Lab Recherche Musees Fr 1970, 8-24.

11. Doménech-Carbó, M.T. Novel analytical methods for characterizing binding media and protective coatings in artworks. Anal. Chim. Acta 2008, 621, 109-139. [CrossRef]

12. Fremout, W.; Dhaenens, M.; Saverwyns, S.; Sanyova, J.; Vandenabeele, P.; Deforce, D.; Moens, L. Tryptic peptide analysis of protein binders in works of art by liquid chromatography-tandem mass spectrometry. Anal. Chim. Acta 2010, 658, 156-162. [CrossRef] [PubMed]

13. Lluveras, A.; Bonaduce, I.; Andreotti, A.; Colombini, M.P. GC/MS analytical procedure for the characterization of glycerolipids, natural waxes, terpenoid resins, proteinaceous and polysaccharide materials in the same paint microsample avoiding interferences from inorganic media. Anal. Chem. 2010, 82, 376-386. [CrossRef] [PubMed]

14. Kuckova, S.; Hynek, R.; Kodicek, M. Application of peptide mass mapping on proteins in historical mortars. J. Cult. Herit. 2009, 10, 244-247. [CrossRef]

15. Nevin, A.; Comelli, D.; Valentini, G.; Anglos, D.; Burnstock, A.; Cather, S.; Cubeddu, R. Time-resolved fluorescence spectroscopy and imaging of proteinaceous binders used in paintings. Anal. Bioanal. Chem. 2007, 88, 1897-1905. [CrossRef] [PubMed]

16. Dallongeville, S.; Garnier, N.; Rolando, C.; Tokarski, C. Proteins in art, archaeology, and paleontology: From detection to identification. Chem. Rev. 2015, 116, 2-79. [CrossRef] [PubMed]

17. Wolbers, R.; Landrey, G. The Use of Direct Reactive Fluorescent Dyes for the Characterization of Binding Media in Cross Sectional Examinations; American Institute for Conservation: Washington, DC, USA, 1987; pp. 168-202.

18. Messinger, J.M. Ultraviolet-Fluorescence Microscopy of Paint Cross Sections: Cycloheptaamylose-Dansyl Chloride Complex as a Protein-Selective Stain. J. Am. Inst. Conserv. 1992, 31, 267-274. [CrossRef]

19. Sandu, I.C.A.; Roque, A.C.A.; Matteini, P.; Schäfer, S.; Agati, G.; Correia, C.R.; Viana, J.F.F.P. Fluorescence Recognition of Proteinaceous Binders in Works of Art by a Novel Integrated System of Investigation. Microsc. Res. Tech. 2012, 75, 316-324. [CrossRef]

20. Kuckova, S.; Sandu, I.C.A.; Crhova, M.; Hynek, R.; Fogas, I.; \& Schafer, S. Protein Identification and Localization Using Mass Spectrometry and Staining Tests in Cross-Sections of Polychrome Samples. J. Cult. Her. 2013, 14, 31-37. [CrossRef]

21. Dallongeville, S.; Richter, M.; Schäfer, S.; Kühlenthal, M.; Garnier, N.; Rolando, C.; Tokarski, C. Proteomics Applied to the Authentication of Fish Glue: Application to a 17th Century Artwork Sample. Analyst 2013, 138, 5357-5364. [CrossRef] [PubMed]

22. Sandu, I.C.A.; Murta, E.; Veiga, R.; Muralha, V.S.F.; Pereira, M.; Kuckova, S.; Busani, T. An Innovative, Interdisciplinary, and Multi-Technique Study of Gilding and Painting Techniques in the Decoration of the Main Altarpiece of Miranda Do Douro Cathedral (XVII-XVIIIth Centuries, Portugal). Microsc. Res. Tech. 2013, 76, 733-743. [CrossRef]

23. Magrini, D.; Bracci, S.; Sandu, I.C.A. Fluorescence of Organic Binders in Painting Cross-Sections. Procedia Chem. 2013, 8, 194-201. [CrossRef]

24. Martins, S. An Efficient Methodology for the Synthesis of 3-Styryl Coumarins. J. Braz. Chem. Soc. 2012, 23, 688-693. [CrossRef]

25. Gordo, J.; Avó, J.; Parola, A.J.; Lima, J.C.; Pereira, A.; Branco, P.S. Convenient synthesis of 3-vinyl and 3-styryl coumarins. Org. Lett. 2011, 13, 5112-5115. [CrossRef] [PubMed]

26. Martins, S.; Branco, P.S.; María, C.; Sierra, M.A.; Pereira, A. New methodology for the synthesis of 3-substituted coumarins via palladium-catalyzed site-selective cross-coupling reactions. Synlett 2010, 19, 2918-2922. [CrossRef]

27. Gee, K.R.; Archer, E.A.; Kang, H.C. 4-Sulfotetrafluorophenyl (STP) esters: New water-soluble amine-reactive reagents for labeling biomolecules. Tetrahedron Lett. 1999, 40, 1471-1474. [CrossRef]

28. Quye, A.; Strlič, M. Ethical Sampling Guidance; Institute of Conservation: London, UK, 2019.

29. Salvador, C.; Branco, A.; Candeias, A. Innovative approaches for immunodetection of proteic binders in art. E-Conserv. J. 2016, in press. [CrossRef]

30. Salvador, C.; Bordalo, R.; Silva, M.; Rosado, T.; Candeias, A.; Caldeira, A.T. On the conservation of easel paintings: Evaluation of microbial contamination and artists materials. Appl. Phys. A 2017, 123, 80. [CrossRef] 
31. Bradford, M.M. A rapid and sensitive method for the quantitation of microgram quantities of protein utilizing the principle of protein-dye binding. Anal. Biochem. 1976, 72, 248-254. [CrossRef]

32. Petty, H.R. Fluorescence Microscopy: Established and Emerging Methods, Experimental Strategies, and Applications in Immunology. Microsc. Res. Tech. 2007, 709, 687-709. [CrossRef]

33. Sameiro, M.; Gonçalves, T. Fluorescent labeling of biomolecules with organic probes. Chem. Rev. 2009, 109, 190-212. [CrossRef]

(C) 2019 by the authors. Licensee MDPI, Basel, Switzerland. This article is an open access article distributed under the terms and conditions of the Creative Commons Attribution (CC BY) license (http://creativecommons.org/licenses/by/4.0/). 